DOI: $10.5613 /$ rzs.48.1.5

\section{Tihana Rubić}

\section{Nezaposleni u gradu: antropologija rada $\mathbf{i}$ neformalne ekonomije u Hrvatskoj}

Zagreb: Hrvatsko etnološko društvo, 2017, 312 str.

U Hrvatskoj su od kraja devedesetih godina 20. stoljeća društvene znanosti vrlo produktivne kad je riječ o analiziranju stanja, odnosno zbivanja na nacionalnom tržištu rada. Koji su sektori u porastu a koji u opadanju od osamostaljenja države, koji je tip uslužnih djelatnosti najpopularniji, raste li postotak nezaposlenih $\mathrm{u}$ tranzicijskom periodu - samo su neka od pitanja na koja su sociolozi, ekonomisti i drugi znanstvenici društvene provenijencije nastojali odgovoriti unutar svojih istraživanja. No područje rada pokazalo se zanimljivim i u širem smislu, povrh praćenja trendova na tržištu rada, pa su se neki istraživači tako koncentrirali na s njime povezan problem siromaštva, drugi su se, primjerice, bavili rodnom segregacijom rada, a u fokus je došao i nematerijalni rad, konkretno fenomen kreativnih industrija.

Intrigantni su i oni tekstovi koji su preobrazbi sfere rada u Hrvatskoj od devedesetih godina 20. stoljeća naovamo pristupili kao integralnoj temi općenitijeg značenja te ju problematizirali stavljajući u fokus širi društveni kontekst. Posve je shvatljivo da se ve- ćina autora pri razmatranju izvanjskih okolnosti koje su utjecale na promjene $\mathrm{s}$ radom u nacionalnoj sferi oslanjala na djela teoretičara društva uvaženih u globalnim razmjerima, poput primjerice Ulricha Becka ili Richarda Sennetta, u kojima je unutar narativa o kasnoj moderni, odnosno novom kapitalizmu analizirano i područje ljudskog rada.

Pokazalo se da se, s obzirom na šire socioekonomske parametre zbog kojih rad kao temeljna ljudska djelatnost i s njime povezano tržište ni u kraćim vremenskim sekvencama nisu statični, nego se intenzivno, katkad i stubokom mijenjaju, pojedine subdiscipline upućene na istraživanje tog područja nalaze pred velikim izazovima te da postoje dobri razlozi za interdisciplinarno pristupanje toj temi. Usto, na transformaciju rada utječu i fenomeni nacionalnog karaktera poput društvene, političke i ekonomske tranzicije iz socijalističkog u postsocijalistički sustav kroz koju je Hrvatska prolazila krajem 20. stoljeća te se tako dodatno umnažaju teorijski i empirijski aspekti koje svako proučavanje rada većeg obuhvata $i$ višeg praga kompetencije treba imati u vidu.

Tihana Rubić, docentica s Odsjeka za etnologiju i kulturnu antropologiju Filozofskog fakulteta Sveučilišta u Zagrebu, bila je dobro upoznata s opisanim naporima i poteškoćama istraživača u Hrvatskoj kad je sama 2007. godine započela istraživati nezaposlenost i $\mathrm{s}$ njome povezanu neformalnu ekonomiju. Stoga treba istaknuti njezinu hrabru odluku da pokuša oblikovati vlastiti etnološki i kulturnoantropološki pri- 
stup tom problemu. Nije joj nit vodilja pritom bilo toliko dovođenje u pitanje tuđih pristupa i nalaza koliko ostvarivanje specifičnoga metodološkog doprinosa na ovom istraživačkom području. Naime, kvantitativna je metodologija dugo vremena izrazito prevladavala $\mathrm{u}$ društvenoznanstvenim istraživanjima rada u Hrvatskoj, a deficit kvalitativnih istraživanja ostavio je prazan prostor koji se dao dobro ispuniti. Doduše, krila se u tome i opasnost od eventualnoga pretencioznog, s metodološkim oruđem neusklađenoga postavljanja opsega i ciljeva istraživanja, no nju je Tihana Rubić vješto izbjegla. Naime, svoju je »fokusnu skupinu« našla među stanovnicima jednoga rubnog, starijeg zagrebačkog naselja, koji su u devedesetim godina 20. stoljeća ostali bez formalnog zaposlenja te su u vrijeme provođenja istraživanja, kad su imali između 50 i 65 godina, svi dijelili sličnu sudbinu dugotrajno »nezaposlenih u gradu«, ali i »zaboravljene generacije«. Riječ je o tome da su njihove »strategije snalaženja« bile pomalo u sjeni recentnijih problema mlađih generacija koje je zahvatila novija ekonomska kriza potkraj prvog desetljeća 21. stoljeća, zaoštravajući još itekako prisutne, bolne posljedice privatizacijskih propusta te kasnijih lutanja visoke politike.

Knjiga Nezaposleni u gradu antropologija rada $i$ neformalne ekonomije iznosi na vidjelo kako izgleda životna svakodnevica te skupine nezaposlenih osoba i što oni govore o vlastitim radnim angažmanima, no ne čini to samo zato da bi »ispravila neprav- du« koja im je nanesena svojevrsnim prekrivanjem njihovih životnih putanja javnom i medijskom tišinom, već su autoričine ambicije kudikamo šire. Kao što to drugi dio naslova sugerira, Tihana Rubić ide za time da iz disciplinarnog motrišta razbije ustaljene, mahom pogrešne pretpostavke o »običnim ljudima« i njihovim mukama s »preživljavanjem«. Pronalazeći rad i radne prakse onkraj plaćenih poslova te prepoznajući »ljudski lik« koji stoji iza različitih djelatnosti koje potpadaju pod neformalnu ekonomiju, ona zorno demonstrira koliko je terensko istraživanje - ponajprije intervjui s kazivačima, ali i sudjelujuće promatranje - bitno da bi se doznalo ono što kvantitativni podaci po svojoj prirodi ne mogu otkriti. Višekratno razgovarajući s ljudima, participirajući u njihovim dnevnim ritmovima te prateći njihove sudbine kroz dulji period, autorica je došla do zanimljivih uvida koje je mogla usporediti s medijskim diskursom, s arhivskim materijalima, pa i s vlastitim »predrasudama« o pojedinim aspektima života ranjivih skupina na tržištu rada. Otuda je njezina priča o radu istodobno i priča o gradu, o ratu, o migracijama, o privatizaciji, naposljetku i o potrošnji. No, unatoč višeslojnosti, ta je priča pomno strukturirana te se ne raspršuje u suvišnim digresijama niti prelazi unaprijed zacrtane tematske okvire.

Rezultati autoričinog istraživanja izloženi su u središnjem, najopsežnijem dijelu knjige, a osim kraćeg uvoda, prethodi im iznošenje polazišta i ciljeva te metodološki okvir i napomene. U 
tim dvama poglavljima autorica je vrlo jasna i precizna te iznimno korektna $\mathrm{u}$ težnji da prezentira široki spektar istraživanja s kojima njezino istraživanje komunicira. Oprezna je i glede tumačenja vlastitih metodoloških preferencija $i$ izbora, nastojeći komparativno sagledati njihove prednosti i nedostatke.

Budući da se Tihana Rubić u apostrofiranoj središnjoj cjelini knjige pod naslovom »Istraživanje: građa, analiza i interpretacija« usredotočuje na sudbinu dugotrajno nezaposlenih, čija sjećanja na formalnu zaposlenost sežu još $u$ vrijeme socijalističke Jugoslavije, osim tranzicijskih devedesetih godina 20 . stoljeća, i razdoblje socijalizma logična je okosnica narativa što ih je ona istraživački prikupila. Autoricu kod obiju referentnih točaka njezinih sugovornika - socijalizma i tranzicije - posebno zanimaju područje neformalne ekonomije, uloga obitelji te položaj žene na tržištu rada.

Ona tako, između ostaloga, razmatra kako se u koje vrijeme društveno legitimirao rad »u fušu« ili rad »na crno«, opstaje li institucija »baka-servisa« u izmijenjenom urbanom kontekstu te pri bržem tempu života, potpomažu li roditelji svoju djecu financijski i nakon što ona odrastu, mijenja li se i kako uloga žene u kućanstvu te postaju li žene sve češće hraniteljicama obitelji zbog nezaposlenosti muževa.

Svoju pozornost ujedno usmjerava na način života nezaposlenih u gradu, od njihova funkcioniranja u konkretnom prigradskom naselju u kojem žive preko praćenja njihova radno, dokoli- čarski ili pak potrošački motiviranog cirkuliranja po drugim dijelovima grada pa do ustanovljavanja njihovih poriva za odlaskom na "grunt«, u vikendicu ili na selo u posjet rodbini.

Kao zanimljiv motiv pritom isplivavaju i susjedski odnosi, kako međusobna ispomoć i podrška, tako i ljubomora te etničko ili kakvo drugo, ideološko raslojavanje. Tranzicijski i privatizacijski kontekst u prvi plan dovlači i odnos ljudi prema državi, politici i institucijama sustava, pa i konkretno pitanje povjerenja u mirovinski sustav.

Prije no što nudi zaključnu interpretaciju i problematizaciju nezaposlenosti na osnovi provedenoga teorijskog i empirijskog istraživanja, Tihana Rubić još na kraju toga četvrtog poglavlja podastire tri »studije primjera« u čijim su središtima dvije nezaposlene žene i jedan muškarac te preko kojih dolazi do izražaja i specifični narativni doprinos kulturne antropologije ovoj istraživačkoj temi. O odnosu glavnih protagonista prema poslu, djeci, novcu, mirovini, slobodnom vremenu, politici tako smo u prilici doznati iz uravnotežene kombinacije fragmenata njihovih iskaza, autoričinih impresija oblikovanih u gotovo pa književni izričaj te referenci i fusnota koje podsjećaju na važnost znanstvene preciznosti i ozbiljnosti kod pristupanja fenomenu nezaposlenosti koji je prečesto predmetom laičkoga rezoniranja.

Zaključak knjige pruža naknadni autoričin pogled na njezine vlastite istraživačke i prezentacijske strategije te dodatno obrazlaganje pojedinih odlu- 
ka i odabira. Sve okončava sumiranjem pet glavnih teza i ciljeva, među kojima vrijedi istaknuti »drukčije, dinamično i složenije ‘čitanje' nezaposlenosti«, koje je u svakom pogledu ostvareno. Knjiga sadržava i sažetak na engleskom jeziku te iscrpan popis korištene literature.

Imajući u vidu makro- i mikroprocese kojima je hrvatsko društvo izloženo u posttranzicijsko vrijeme, napose njihove učinke na svijet rada, lako je pretpostaviti da će tema rada u užem i širem smislu i nadalje biti atraktivna brojnim istraživačima u Hrvatskoj. Teško je pak zamisliti da bi ijedno buduće društveno-humanističko promišljanje rada i njemu srodnih fenomena nezaposlenosti i neformalne ekonomije moglo zaobići znanstvenu monografiju Tihane Rubić kao jednu od najvažnijih referenci.

\section{Ozren Biti}

Institut za etnologiju i folkloristiku, Zagreb 